\title{
The Evolution of Cell Free Biomanufacturing
}

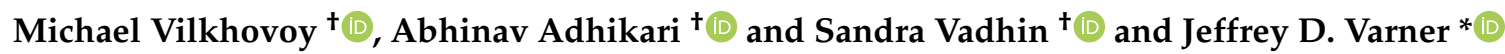 \\ Robert Frederick Smith School of Chemical and Biomolecular Engineering, Cornell University, Ithaca, NY 14850, \\ USA; mv396@cornell.edu (M.V.); aa2663@cornell.edu (A.A.); sv442@cornell.edu (S.V.) \\ * Correspondence: jdv27@cornell.edu \\ + These authors contributed equally to this work.
}

Received: 31 March 2020; Accepted: 19 May 2020; Published: 8 June 2020

\begin{abstract}
Cell-free systems are a widely used research tool in systems and synthetic biology and a promising platform for manufacturing of proteins and chemicals. In the past, cell-free biology was primarily used to better understand fundamental biochemical processes. Notably, E. coli cell-free extracts were used in the 1960s to decipher the sequencing of the genetic code. Since then, the transcription and translation capabilities of cell-free systems have been repeatedly optimized to improve energy efficiency and product yield. Today, cell-free systems, in combination with the rise of synthetic biology, have taken on a new role as a promising technology for just-in-time manufacturing of therapeutically important biologics and high-value small molecules. They have also been implemented at an industrial scale for the production of antibodies and cytokines. In this review, we discuss the evolution of cell-free technologies, in particular advancements in extract preparation, cell-free protein synthesis, and cell-free metabolic engineering applications. We then conclude with a discussion of the mathematical modeling of cell-free systems. Mathematical modeling of cell-free processes could be critical to addressing performance bottlenecks and estimating the costs of cell-free manufactured products.
\end{abstract}

Keywords: cell-free systems; cell-free protein synthesis; synthetic biology

\section{Introduction}

Cell-free biology is an emerging technology for research and the point-of-care manufacturing of a wide array of macromolecular and small molecule products. A distinctive feature of cell-free systems is the absence of cellular growth and maintenance, thereby allowing the direct allocation of carbon and energy resources toward a product of interest. Moreover, cell-free systems are more amenable than living systems to observation and manipulation, hence allowing rapid tuning of the reaction conditions. Recent advances in cell-free extract preparation and energy regeneration mechanisms have increased the versatility and range of applications that can be produced. Thus, the cell-free platform has evolved from merely an investigative research tool to a promising alternative to traditionally used living systems for biomanufacturing, as well as biological research. In combination with the rise of synthetic biology, cell-free systems today have not only taken on a new role as a promising technology for just-in-time manufacturing of therapeutically important biologics and high-value small molecules, but have also been utilized for applications such as biosensing, prototyping genetic parts, and metabolic engineering. They have also been used as educational tools at the high school and undergraduate levels for understanding synthetic biology due to their ease of use, rapid response times, and the availability of commercial kits for different cell-free platforms including Escherichia coli, Chinese hamster ovary (CHO), HeLa, and plant cells [1-3]. Thus, cell-free technologies are promising tools that will likely be at the center of many future synthetic biology applications.

Arguably, today, the most widely used cell-free technology is cell-free protein synthesis (CFPS), an in vitro platform for protein transcription (TX) and translation (TL). The role of 
CFPS in research is not new (Figure 1); cell-free systems have been used for decades to explore fundamental biological mechanisms. For example, some of the first uses of CFPS were in the 1950s by Borsook [4] and Winnick [5], who used animal tissue homogenates to study how amino acids were incorporated into proteins. A few years later, Staphylococcus aureus extracts were used to confirm amino acid incorporation [6]. In 1956, the role of adenosine triphosphate (ATP) in protein production was discovered using rat liver extracts [7], and Nirenberg and Matthaei [8,9] demonstrated templated translation, i.e., the now familiar codon code, using E. coli cell-free extracts (this work later led to a Nobel Prize in 1968). What arguably could be recognized as the first precursor to modern cell-free transcription and translation applications was developed in 1967 by Lederman and Zubay [10]; they developed a coupled transcription-translation bacterial extract that allowed DNA to be used as a template. Shortly after, Spirin and coworkers improved cell-free extract protein production with a continuous exchange of reactants and products, allowing the system to run for tens of hours; however, these systems could only synthesize a single product and were energy limited [11]. More recently, the energy efficiency of E. coli CFPS was improved by generating ATP with substrate level phosphorylation [12] and oxidative phosphorylation in the Cytomim system [13-15]. The use of glucose as an energy source was also explored [16]. Since oxidative phosphorylation is a membrane associated process, the study of Swartz and colleagues revealed that membrane dependent energy metabolism can be activated in a cell-free system, suggesting complex metabolism is still occurring. Another platform, myTXTL [17], uses a different metabolic process that couples ATP regeneration and inorganic phosphate recycling to extend the duration of protein production. Synthetic genetic circuitry can also be constructed to control gene expression using a variety of approaches. Bacteriophage RNA polymerases are commonly used in CFPS for transcription. However, the use of a vast array of bacterial regulatory elements based on the sigma factor family has recently been explored, allowing multi-layer genetic cascades to be easily implemented [17-19]. Thus, the developments in CFPS have expanded its repertoire of applications, enabling it to be a viable alternative to living systems for not only investigative research, but also bioengineering and biomanufacturing at both small and large scales.

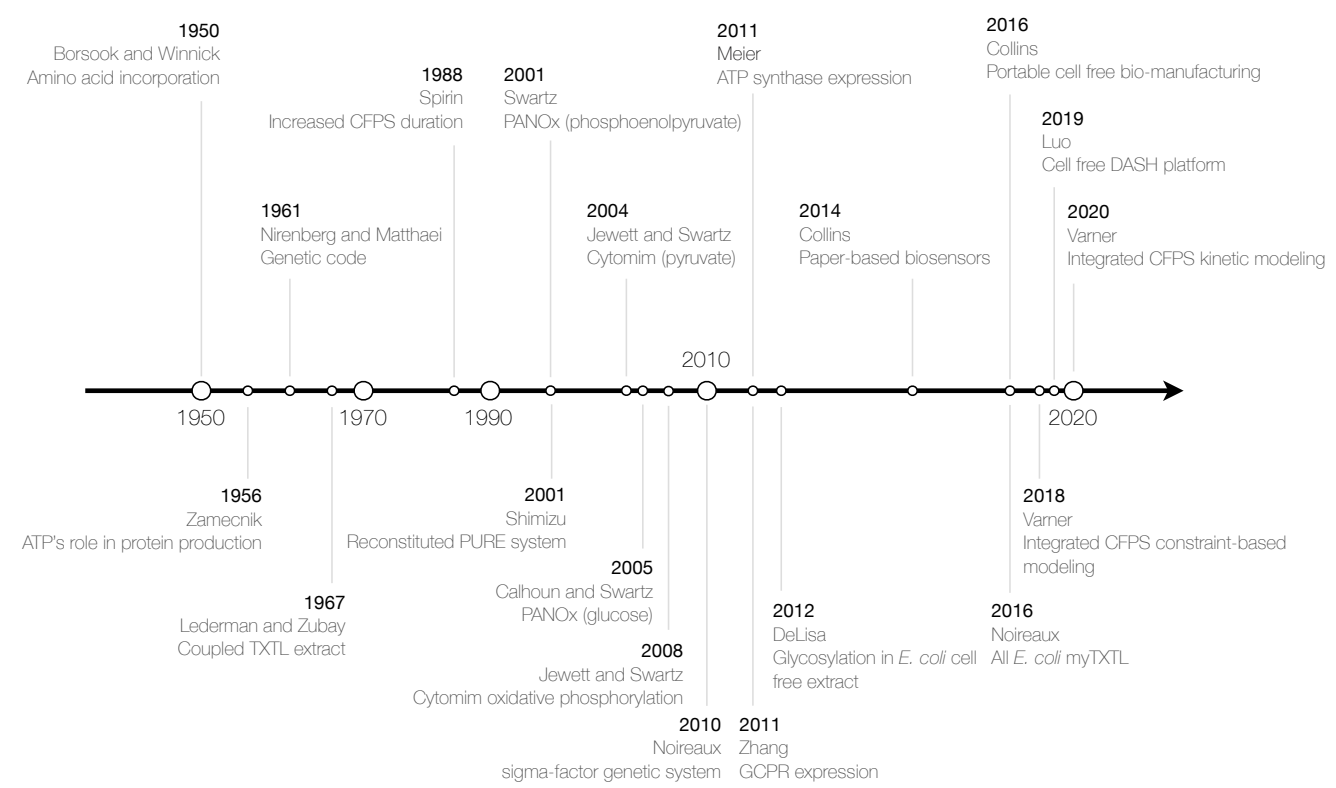

Figure 1. Time line for milestones in the evolution of cell-free systems since 1950 until now. Abbreviations: cell-free protein synthesis (CFPS), G-coupled protein receptor (GCPR), transcription and translation (TXTL), CFPS system energized by PEP (PANOx), DNA-based Assembly and Synthesis of Hierarchical (DASH), commercially available E. coli cell free extract (myTXTL, Arbor Biosciences). 
In this review, we discuss the evolution of cell-free technologies, in particular advancements in extract preparation, cell-free protein synthesis, and cell-free metabolic engineering applications. We then conclude with a discussion of the mathematical modeling of cell-free systems. Mathematical modeling of cell-free processes could be critical to addressing performance bottlenecks and estimating the costs of cell-free manufactured products.

\section{Origin and Preparation of Cell-Free Extracts}

There are two broad classes of cell-free systems: crude cell lysates and reconstituted systems. While crude extract-based systems, commonly prepared from E. coli, S. cerevisiae, rabbit reticulocytes, wheat germ, and insect cells [20], consist of the biocatalysts remaining after cell lysis, reconstituted systems are well defined, prepared using only the factors essential for protein synthesis: purified enzymes, tRNAs, ribosomes, amino acids, and energy molecules. The first purified extract of this kind, the Protein synthesis Using Recombinant Elements (PURE) system, was developed by Shimizu et al. in 2001 [21]. A similar system, based on Thermus thermophilus, was later developed by Zhou et al. [22]. Other specialized systems based on PURE have also been developed [23-26]. These specialized systems have been utilized in applications including the synthesis of disulfide-bonded functional aglycosylated immunoglobulin G (IgG) and G-protein coupled receptors and the study of the effects of liposomes on the solubility of aggregation-prone membrane proteins. Such reconstituted systems offer two main advantages over crude extracts. First, they are a valuable research tool for studying biological processes including protein expression and folding in the context of a completely defined reaction mixture. For example, given the precise knowledge and control of the components in the reconstituted system, it is possible to study the role of individual additions such as chaperones, translation elongation factors, ribosome release factors, and other molecules. Li et al., in a study analyzing the influence of such additions in the PURE system, showed that the efficiency of protein synthesis was limited by translation elongation capacity, ribosome release, and ribosome recycling. When the authors changed the ratio of elongation factors, release factors, and recycling factors to ribosome concentration to more closely resemble in vivo conditions, a five-fold improvement in the yield of firefly luciferase reporter protein was observed [27]. The second advantage of reconstituted systems, such as the PURE system, is that they do not contain proteases and nucleases, further improving the production of many proteins [28]. Despite these advantages, reconstituted systems suffer from two major drawbacks: a higher cost ( $\$ 0.99 / \mu \mathrm{L}$ for a PURE reaction vs. $\$ 0.15-0.57 / \mu \mathrm{L}$ for a crude extract reaction; price for commercial kits [3]) and typically lower yields [29]. In this regard, crude cell extracts prevail; they are less expensive, especially for reactions carried out at larger scales [28]. They also offer more complex metabolic capabilities that can be exploited for energy regeneration, extending the duration of protein synthesis. Toward these advantages, the preparation of crude cell-free extracts, which has undergone a significant evolution since the early applications in the 1950s and 1960s, is now an area of considerable focus.

Cell-free extracts are commonly derived from crude cell extracts, where the cell's transcription and translation machinery is retained while cellular debris and chromosomal DNA are discarded (Figure 2). Cells are typically grown until they reach the exponential phase, when they are harvested and lysed commonly using a high pressure homogenizer or a specialized bead mill [30]. Early extracts were prepared by centrifugation of lysates at $30,000 \times \mathrm{g}$ followed by the addition of a mixture of amino acids, adenosine triphosphate (ATP), and other energy molecules, salts, and buffer [31,32]. In the early 2000s, several changes were made by different research groups to make the extract preparation protocol more efficient including centrifugation at a lower rate $(12,000 \times g)$, the use of shake flask fermentation, and the overexpression of the T7 RNA polymerase in the commercial BL21 (DE3) E. coli strain during extract preparation [33-35]. Alternatives to the high pressure homogenization step, which include the use of bead vortex mixing [30] or lytic enzymes [36], have also been recently explored. It is also possible to delete or overexpress certain genes in the source cell to yield customized cell-free extracts. For example, the Swartz group made several gene deletions in E. coli A19 cells before harvesting and extract preparation, improving the protein yield in the extract by up to $250 \%[37,38]$. 
More recently, a new extract design scheme was implemented by Jewett lab to mix different extracts combinatorially, each containing a unique overexpressed enzyme, to construct a full biosynthetic pathway [39]. The same group also optimized the extract preparation procedure to better accommodate the use of genetic circuits [40]. These developments showed that the extract preparation process can be modified depending on the end goal. However, there are still important unanswered questions in extract preparation. For instance, it still remains to be explored how one can selectively delete enzymes only in cell-free extracts. Continued research in this area could pave the way for minimal extracts highly optimized for a known application.

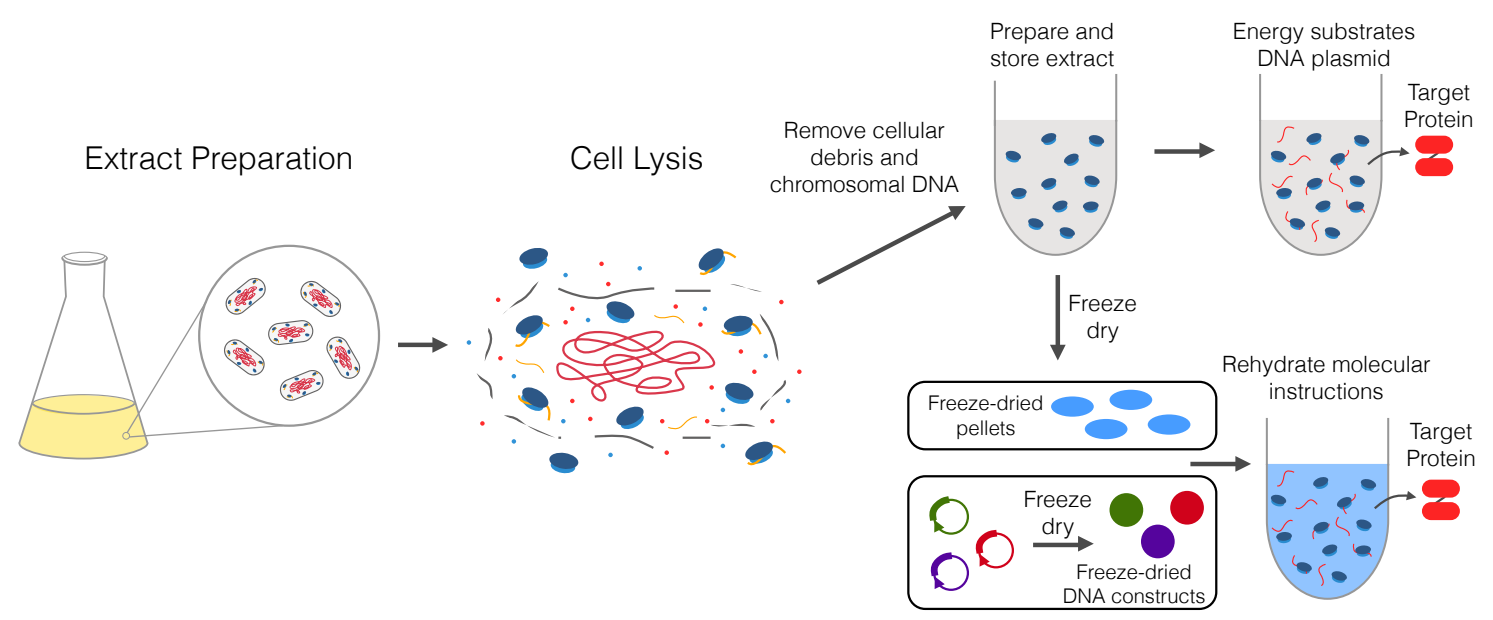

Figure 2. Schematic of cell-free protein synthesis. Cell extract is prepared by cell lysis, and cellular debris and chromosome DNA is removed. An energy source along with the necessary amino acids, nucleotides, and cofactor are added to the cell-free reaction. Template DNA of the target protein is added. The target protein is then easily purified from the cell-free system. Alternatively, cell-free extract can be freeze dried into pellets and paired with lyophilized DNA. Through the simple addition of water, proteins can be manufactured on site and on demand. Figure adapted from [41,42].

\section{Applications of Cell-Free Technologies}

\subsection{Cell-Free Production of Biologics and Specialized Proteins}

Cell-free protein synthesis (CFPS) has been utilized in a wide range of applications from the expression of pharmaceutical proteins [43-45] to the production of libraries for protein evolution and structural genomics [46]. Complex post-translational modifications that are typically difficult to carry out using bacterial extracts have also recently been achieved cell-free. For example, $\mathrm{N}$-linked glycoproteins have been produced in an E. coli-based cell-free extract with the addition of a purified oligosaccharyltransferase (OST) and its lipid-linked oligosaccharides (LLOs) [47]. A single-pot glycoprotein synthesis system was also developed, potentially allowing for the production of personalized protein therapeutics [48]; in this system, the OSTs and LLOs were expressed in the E. coli host strain, which resulted in glycosylation-competent lysates. Other specialized proteins have also been produced in cell-free systems. The ability to add membrane mimics such as surfactants or liposomes to the extract as stability agents has allowed the production of membrane proteins [49-52]. Vaccines [45,53], protein assemblies [54-56], and proteins incorporating non-natural amino acids [57-59] have also been synthesized using CFPS systems. Disulfide-bonded proteins and antibodies have also been synthesized by adding components that facilitate the formation of these bonds in the mixture such as glutathione reductase, thioredoxin reductase, iodoacetamide, and disulfide isomerase (DsbC) [25,28,60,61]. Cytosol-penetrating antibodies have also been synthesized [62]. The cell-free synthesis of onconase, a cytotoxic cancer therapeutic, has also been demonstrated [63]. Point-of-care protein manufacturing is also possible when microfluidic reactors are used. Compared to batch reactions, continuous flow microreactors typically offer users more 
precise control over mixing [64,65]. An automated on-chip CFPS reactor has been developed that runs transcription and translation reactions simultaneously, but in separate compartments [66]. Each process can be optimized independently, and the quasi-continuous supply of new mRNA from the TX chamber to the TL chamber allows for a longer CFPS reaction and increased protein yield. Other microfluidic platforms integrate purification methods like dialysis and affinity chromatography $[67,68]$. For example, cecropin B, an antimicrobial peptide that is widely used to control biofilm-associated diseases, has been produced at a clinically-relevant dose in a few hours using a microfluidic device with on-chip protein purification [68]. A continuous exchange microfluidic reactor using a nanofabricated membrane to allow for extended reaction times and improved yields has also been developed with the goal of producing single-dose therapeutic proteins at the point-of-care [69]. Moreover, cell-free extracts can be lyophilized and stored at $-80{ }^{\circ} \mathrm{C}$ for more than a year without degradation [28]. They can then be rehydrated with water and then incubated using the body's heat to activate the extract components, highlighting the portability and versatility of the cell-free platform [70].

Lastly, while the majority of CFPS has been carried out in small scales, there have been continued efforts to scale-up the technology. For example, the scalability of cell-free systems has been explored in a few academic studies [71-74]. Moreover, there are also a few examples of industrial-scale cell-free protein production for high-value products such as antibodies and cytokines [73,75] as well as industrial implementations of the technology, most notably by the clinical stage company Sutro Biopharma and the GreenWorX platform of GreenLight Biosciences. Continued research in the area of scale-up will potentially accelerate industrial adaptation.

\subsection{Cell-Free Systems in Synthetic Biology}

Applications of cell-free systems in synthetic biology are varied, from diagnostics to fundamental discovery and prototyping. Biosensing is an area where cell-free systems have recently proven useful. They possess a unique advantage over whole cells because of their ability to detect species that are cytotoxic or impermeable to the cell wall [70]. These systems have been deployed to detect pathogens such as norovirus [76], Ebola virus [77], and Zika virus [78]. In addition, initial studies have shown that paper-based cell-free sensors can detect the presence of heavy metals such as mercury and drugs such as $\gamma$-hydroxybutyrate, by utilizing the transcriptional regulators, MerR and BlcR, respectively [79]. The portability offered by these systems further underscores their usefulness in the field. CFPS has also been used in the development of minimal cells, the simplest cellular mimics that consist of only the genes essential for survival. Minimal cells are often described as biological analogs to the hydrogen atom, which has served to uncover many fundamental phenomena in chemistry [80]. Their bottom-up construction has been made possible mainly by the advancements in two areas: compartmentalization strategies and programmable genetic circuits [17,81-84]. Toward this goal, proteins have been expressed in compartments such as liposomes $[17,85]$, phospholipid vesicles $[19,83]$, and hydrogel particles [86], and genetic circuits that encode oscillations [87,88], negative feedback loops [89], or riboswitches acting as regulatory elements [90] have been developed in CFPS systems. Interacting minimal cells have also been developed [91]. Recently, the construction of dynamic biomaterials powered by artificial metabolism was also demonstrated by Hamada and coworkers, with applications ranging from locomotion, pathogen detection, and hybrid nanomaterials [92]. Cell free systems have also been used for prototyping novel genetic parts or circuits before using them in vivo. Prototyping can be done more efficiently in cell-free systems because of the tighter control over plasmid dosage, inducer concentrations, $\mathrm{pH}$, temperature, and salt concentrations [70]. The ability to use linear PCR templates in cell-free systems further accelerates this process [70]. Moreover, developments in experimental setup and analysis techniques such as the use of acoustic liquid-handling robots [93], real-time fluorescent reporters [94], microfluidics [95], and droplet-based expression [96] have allowed the prototyping to be carried out at high-throughput rates [70]. The relative ease of manipulating cell-free systems makes them attractive tools for investigating complex processes. 


\subsection{Cell-Free Metabolic Engineering}

Cell-free systems have gained wide interest in metabolic engineering applications, primarily to circumvent the significant barriers of traditional in vivo processes [97]. For example, a major challenge in in vivo metabolic engineering is achieving high flux through synthetic pathways of interest. This is because cells have their own objectives, e.g., growth or maintenance, which drives metabolic flux away from the desired pathways. The complexity of living cells also makes computational modeling and optimization of metabolic flux difficult [98]. Cell-free systems, on the other hand, can be accurately modeled and the reaction environment tuned according to the bio-synthetic needs. They offer many advantages for the study, manipulation, and modeling of metabolism. Central amongst these is direct access to metabolites and the biosynthetic machinery without the interference of a cell wall. This allows interrogation of the chemical microenvironment, while the biosynthetic machinery is operating, potentially at a fine time resolution. Eliminating the need to maintain cell viability also allows the full allocation of energy resources to the production of products of interest. Because of these benefits, various metabolic engineering endeavors have been made in both purified and crude cell extracts with promising results.

Several strategies have been implemented in CFME to increase flux through enzymatic pathways and improve product yield. For example, Opgenorth and coworkers [99] designed a molecular purge valve consisting of an $\mathrm{NAD}^{+}$-dependent reductase enzyme, an $\mathrm{NADP}^{+}$-dependent reductase enzyme, and a NADH-specific oxidase to manage the flux of reducing equivalents. This valve was utilized to produce valuable compounds such as polyhydroxybutyrate bioplastic and prenylated natural products [99-101]. The authors carried out efficient synthesis of cannabinoids: up to $1.25 \mathrm{~g} / \mathrm{L}$ and $1.74 \mathrm{~g} / \mathrm{L}$ of the cannabinoid precursors, cannabigerolic acid and cannabigerovarinic acid, respectively, were synthesized, then converted in a one-step reaction using cannabidiolic acid synthase, to cannabidiolic acid and cannabidivarinic acid, respectively [101]. The use of co-immobilized enzymes has also been demonstrated in vitro, allowing their reuse over more than seven cycles and highlighting an important step toward large-scale application [102]. In this study, the regulation and identification of inhibitors of the amorpha-4,11-diene (AD) biosynthetic pathway were also carried out, increasing the $\mathrm{AD}$ synthesis rate up to $5.7 \mu \mathrm{mol} / \mathrm{L} \cdot \mathrm{min}$, an approximately three-fold increase from their previous work ( $2 \mu \mathrm{mol} / \mathrm{L} \cdot \mathrm{min})$ [103]. Other important products such as ethanol [104], n-butanol [105], and ethyl(S)-2-ethoxy-3-(p-methoxyphenyl)propanoate (EEHP) [106], along with next-generation devices such as an aerobic enzymatic fuel cell from glucose have also been demonstrated [107]. A majority of CFME approaches described thus far have used purified enzymes to form biosynthetic pathways. Recently, Dudley and coworkers implemented a novel technique, combining six crude E. coli lysates (each enriched with a unique pathway enzyme) at equal ratios and one lysate (enriched with three unique pathway enzymes) to construct a complete 20-step enzymatic pathway of limonene synthesis from glucose [108]. This system achieved a productivity of $3.8 \mathrm{mg} / \mathrm{L} \cdot \mathrm{h}$ limonene, just two-fold less than the in vivo pathway [109]. In another novel approach, Yi and coworkers [110] used a hybrid system consisting of E. coli and cyanobacteria Synechocystis sp. PCC6803 cell lysates to demonstrate the synthesis of (R,R)-2,3-butanediol (2,3-BD) from starch, utilizing the presence of starch-degrading enzymes in the cyanobacterial lysate. Thus, cell-free technologies have found wide use for the production of high-value small molecule products, at least in the context of research.

Metabolic engineering approaches have also been used to improve cell-free protein synthesis. Calhoun and Swartz [111], for example, performed chromosomal deletions in the source cells to address the problem of cell-free amino acid degradation. Gene overexpression approaches have also been used to improve protein yields [112,113]. CFME has also been used to address certain bottlenecks in CFPS such as the need for energy and cofactor regeneration in cell extracts. One of the early examples involved adding oxalate, $\mathrm{CoA}$, and $\mathrm{NAD}^{+}$to inhibit a futile cycle while producing ATP from pyruvate [12]. More involved metabolic pathways, including the activation of glycolysis and oxidative phosphorylation, have been utilized in different extracts $[13,15,16,111]$. These efforts have paved the way for the use of less expensive energy sources (glucose, pyruvate, or glutamate) and nucleotides 
(NMP), as well as increased the duration of the protein synthesis reactions. Similarly, a novel non-oxidative glycolysis pathway has been designed, enabling $100 \%$ conservation of carbon in sugar catabolism to acetyl-CoA [114]. However, despite these achievements and the advantages of cell-free over in vivo processes, a fundamental challenge remains: the optimization of cell-free production systems. Due to the complexity and immense interconnectivity of metabolic networks, even for simple prokaryotic organisms like E. coli, optimizing network operation toward a desired function is often not intuitive [115]. To this end, the systems-level analyses offered by various mathematical modeling tools, developed for application to in-vivo metabolic optimization problems, could prove indispensable for the systematic design of cell-free system operation.

\section{Mathematical Modeling of Cell-Free Systems}

\subsection{Cell-Free Transcription and Translation Models}

If cell-free systems are to become a mainstream technology for advanced applications such as point-of-care therapeutic manufacturing [41], we must first understand the performance limits of these systems [15]. A critical tool towards this goal is mathematical modeling. There have been several mathematical models of cell-free protein synthesis, with the majority of these models exclusively focusing on transcription and translation (TXTL) processes. These models are mostly systems of ordinary differential equations (ODEs) based on saturation or Hill-like kinetic expressions. As an early example, Karzbrun and coworkers developed a coarse-grained model of transcription and translation for E. coli cell-free extract [116]. To simplify calculations, this model was based on four enzymes and ten parameters. Transcription and translation processes were assumed to follow Michaelis-Menten kinetics. The authors noted that the protein synthesis rate of their system began to exponentially decay after one hour, so their study focused on the first hour of the cell-free experiment. This decay was attributed to resource depletion and waste accumulation, an important practical consideration regardless of the cell-free system used. Stögbauer and coworkers developed a model that accounts for resource consumption and degradation and identified the bottleneck of protein synthesis [117]. Variables representing transcription and translation resources were added to the model, but the exact identities and quantities of these resources were beyond the scope of the study. The authors attempted to use Hill functions to better predict saturation effects of mRNA and their protein of interest, but found that the optimized Hill coefficients were close to one, resulting in Michaelis-Menten-like approximations. Protein yield was determined to be a function of template DNA concentration. This work also found that NTP depletion was not the reason for protein synthesis rate decay; for the specific extract used, ribosome degradation was to blame for rate decay. More recently, Neiß and coworkers published a comprehensive experimentally validated model that identified limiting factors of cell-free protein synthesis [118]. An unusual characteristic of this model was the hybrid black box approach: transcription processes were simplified, while the model for translation was detailed. The entire model was a large system of differential algebraic equations (DAEs); a system of eight algebraic equations and over 400 ODEs. Using sensitivity analysis, Neiß found that cell-free protein synthesis rates were limited by the concentrations of tRNA and elongation factor Tu. A model that captured resource competition in genetic networks was published by Gyorgy and Murry [119]. For a two-protein expression system, simulations that considered both products agreed with the experimental data. This model also predicted possible product concentrations in multiple-protein expression systems and compared different cell-free extracts. The authors concluded that resource competition was a key consideration in the design of synthetic gene circuits. The cell-free protein synthesis models discussed thus far have been based on experiments in which DNA/protein components were used to construct genetic networks. However, RNA genetic circuitry has also been explored in the cell-free platform, and mathematical models for the system have been developed. Transcriptional regulating RNAs are of interest because they bypass the need for regulatory proteins [120]. In the context of circuit design, regulatory RNAs have been used to 
create various logic gates and cascades [121,122]. The first experimentally validated model of a synthetic RNA circuit was published by $\mathrm{Hu}$ and coworkers [123]. The model contained eight ODEs and 13 previously unknown parameters. These parameters were estimated based on results from sensitivity analysis-guided experimental design. Taken together, models of transcription, translation, resource competition, and gene regulatory circuits have provided useful information for optimizing cell-free biomanufacturing or designing new systems; however, they have each provided an incomplete representation of cell-free protein synthesis. CFPS does not just rely on transcription and translation processes, but instead depends on central carbon metabolism and other metabolic pathways to meet energy and carbon precursor requirements. Thus, more sophisticated models are needed that integrate metabolic pathways with transcription and translation processes. Ultimately, an integrated framework could provide insights into the limitations of CFPS and generate strategies for improving performance metrics such as carbon yield, energy efficiency, and productivity.

\subsection{Metabolic Modeling Frameworks}

Traditional approaches to metabolic modeling, which were first developed to describe living cells, could also be applied to cell-free systems, thereby addressing an important current limitation. Decades before the genomics revolution, mechanistically structured in vivo metabolic models arose from the desire to predict microbial phenotypes resulting from changes in intracellular or extracellular states [124]. The single-cell E. coli models of Shuler and coworkers pioneered the construction of large-scale, dynamic metabolic models that incorporated multiple regulated catabolic and anabolic pathways constrained by experimentally-determined kinetic parameters [125]. Shuler and coworkers generated many single-cell kinetic models, including single-cell models of eukaryotes [126,127], minimal cell architectures [128], and DNA sequence-based whole-cell models of E. coli [129]. As biological understanding grew, metabolic models became less reductionist and more detailed. Next-generation models described cellular processes such as RNA synthesis, chromosome synthesis, and regulated catabolic and macromolecular synthesis pathways in detail using ordinary differential equations [130]. For example, Karr et al. (2012) developed a whole cell model of Mycoplasma genitalium, accounting for all genes and their interactions in the cell [131]. The model, which was constructed with independent sub-models describing different components of the cell, successfully described the full cellular life cycle at the level of single molecules. However, while undoubtedly important tools, traditional metabolic modeling approaches are often complex and nonlinear and require the estimation of a large number of unknown parameters; a difficult process because of the inherent noisiness of biological data and the computational burden of repeatedly solving the model equations. To overcome such obstacles, constraint-based methods were developed to describe metabolic networks with only a limited need for kinetic parameters [132].

Stoichiometric reconstructions of microbial metabolism, popularized by constraint-based approaches such as flux balance analysis (FBA), have become standard tools to interrogate metabolism [133]. FBA and metabolic flux analysis (MFA) [134], as well as convex network decomposition approaches such as elementary modes [135] and extreme pathways [136] model intracellular metabolism using the biochemical stoichiometry and other constraints such as thermodynamic feasibility $[137,138]$ under pseudo-steady-state conditions. Constraint-based approaches use linear programming [139] to predict productivity [132,140], yield [132], mutant behavior [141], and growth phenotypes [142] for biochemical networks of varying complexity, including genome-scale networks. Constraint-based models have also been used to identify strategies for the overproduction of desired compounds. These strategies include genetic knockouts or the addition of heterologous enzyme pathways to an organism's metabolic network and have been used in developing useful bacterial strains for the production of biofuels [143], high-value chemicals [144-146], and pharmaceuticals [147,148]. Stoichiometric reconstructions have been expanded to include the metabolic demands for protein synthesis. Allen and Palsson developed sequence-specific constraint-based models, based on the DNA and protein sequences of interest, 
where transcription and translation processes were integrated with metabolism [149]. Since the early work of Allen and Palsson, sequence-specific constraint-based models have been expanded to the genome scale with detailed descriptions of gene expression (ME-model) $[133,142,150]$ and protein structures (GEM-PRO) [151,152]. These expansions have greatly increased the scope of questions stoichiometric reconstructions can explore. For example, constraint-based methods, which are powerful tools to estimate the performance of metabolic networks, could potentially predict nonintuitive strategies to optimize the interaction between metabolism and gene expression in cell-free applications. Thus, the use of integrated constraint-based models for cell-free optimization studies is a promising future research direction.

\subsection{Emergence of Integrated Cell-Free Models}

Modeling the integration of cell-free transcription and translation processes with metabolic pathways remains in its infancy, with only a few published mathematical models [153-155]. Horvath and coworkers developed an ensemble of dynamic E. coli CFPS models using parameters estimated from measurements of metabolite, amino acid, and protein concentrations from CFPS reactions conducted using the PANOx-SPsystem [155]. This work built upon the hybrid cell-free modeling approach of Wayman and colleagues, which integrated kinetic modeling with a rule-based description of allosteric control [156]. By simulating reaction group knockouts, Horvath et al. suggested that cell-free metabolism and protein synthesis were strongly coupled with oxidative phosphorylation and glycolytic flux. On the other hand, to circumvent computationally expensive parameter estimation, Vilkhovoy and coworkers [154] developed an experimentally-validated constraint-based model of CFPS, which integrated the expression of a model protein product with the supply of metabolic precursors and energy (Figure 3). This model coupled transcription and translation processes with available resources using only six adjustable parameters. Model analysis suggested that protein expression in the PANOx-SP system was translationally limited. Further, the same modeling approach, using only a limited number of experimentally-derived parameters, also described protein expression in the myTXTL system, thereby underscoring the power and versatility of the approach. Taken together, the incorporation of complex metabolism with genetic regulatory networks using constraint-based modeling is a promising approach to simulate cell-free systems. Unfortunately, despite these early studies, there remains an unmet need for comprehensive metabolic models of cell-free reactions. However, as experimental methods are developed for cell-free systems, e.g., [157], and benchmark cell-free datasets are published, we expect that the metabolic modeling community will address this shortcoming. 


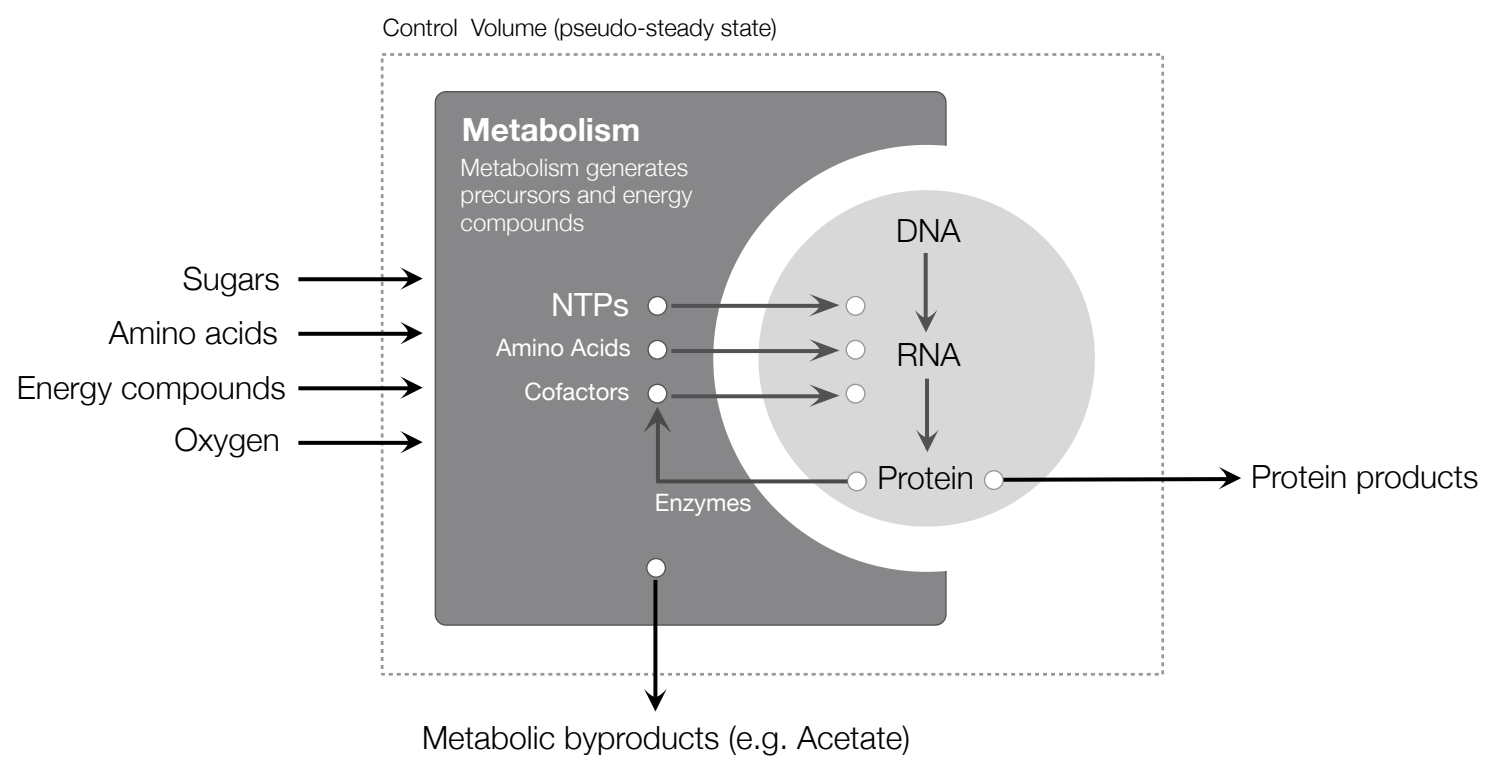

Figure 3. Schematic of the integration of transcription and translation processes with metabolism. Transcription and translation processes demand macromolecular precursors (e.g., NTPs, amino acids, and cofactors) from metabolism for gene expression. The integrated framework is represented as a stoichiometric matrix of metabolites participating in certain reactions, along with a description of the metabolic demands for protein expression. The metabolic flux is estimated subject to constraints, a pseudo-steady-state assumption, and an objective function.

\section{Conclusions}

Cell-free systems have evolved from an investigative tool used since the early 1950s to a sophisticated platform useful for a variety of bioengineering, biomanufacturing, and synthetic biology applications. With the recent advances in extract preparation, improvements in energy regeneration mechanisms, and the ability to perform high-throughput continuous reactions in microfluidic chips, cell-free systems are emerging as a viable alternative to traditional living cells in several application areas. For example, they have become valuable investigative tools for metabolic engineering research, given their tunability and the unfettered access to metabolism without the interference of the cell wall. However, the optimization of cell-free applications remains an important challenge. Toward this challenge, mathematical and computational modeling is a critical tool that could move the platform forward. Models facilitate the understanding of the role of systems-level parameters and interactions, and they also promote the generation of metabolic engineering strategies, for example assisting in making the appropriate genetic manipulation for a desired function, which is not always intuitive. The broad review of the literature presented here highlighted several experimental and computational opportunities that could be addressed in future work. For example, a more detailed description of transcription and translation reactions has been utilized in genome-scale metabolic engineering models, e.g., O'Brien et al. [142]. These template reactions could be adapted to a cell-free system, allowing us to consider important facets of protein production, such as the role of chaperones in protein folding. In addition, post-translational modifications such as glycosylation that are important for the production of therapeutic proteins could also be included in the next generation of cell-free models. Finally, constraint-based modeling could be extended to multi-protein synthetic circuits, RNA circuits, or small molecule production. There are also opportunities to explore with regard to the preparation and manipulation of cell extracts. For example, enabling selective enzyme deletions directly in cell-free extracts, without having these deletions stem from the extract preparation process, could be a game-changing technology. Taken together, continual advancements in modeling and experimental design have paved the way for cell-free systems to become valuable tools for molecular biology research and a promising platform for manufacturing of valuable biotherapeutics and chemicals. 
However, while the popularity of cell-free systems has grown dramatically in the research community, the platform still faces important challenges for biomanufacturing applications, in particular scale-up, the high cost of extracts, and limited post-translational modification capability. While mammalian and insect cell-free systems have post-translational modification machinery, these types of extracts are expensive compared to their bacterial counterparts. Toward this challenge, DeLisa and coworkers $[47,48]$ recently expressed N-linked glycoproteins in E. coli cell-free extracts, opening up possibilities for the production of therapeutically-relevant proteins in bacterial extracts, which have better overall protein yields, are relatively inexpensive, and have easier extract preparation protocols. There have also been studies on the possible scale-up of protein synthesis by several research groups and a few startup biotechnology companies. However, this remains a critical and underserved topic area. Another possible challenge to using cell-free systems for applications such as biosensors, on-demand therapeutics, or even industrial production, is the inability to achieve $100 \%$ lysis of cells during the extract preparation process, resulting in residual contaminating cells. Addressing this concern could be important to meet various Food and Drug Administration (FDA) regulations. Toward this challenge, Smith and coworkers assessed decontamination strategies and showed that sterile filtration and lyophilization effectively removes cell contamination without affecting the protein synthesis capabilities of the system [158]. Thus, while there remain important challenges to be overcome, it is encouraging that several research groups have worked toward addressing the challenges faced by the the platform. However, continued research and development is important to further improve the capabilities of cell-free technology.

Author Contributions: Writing, original draft preparation, M.V., A.A., and S.V.; writing, review and editing, J.D.V. All authors have read and agreed to the published version of the manuscript.

Funding: The work described was supported by the Center on the Physics of Cancer Metabolism through Award Number 1U54CA210184-01 from the National Cancer Institute. The content is solely the responsibility of the authors and does not necessarily represent the official views of the National Cancer Institute or the National Institutes of Health.

Conflicts of Interest: The authors declare no conflict of interest.

\begin{tabular}{|c|c|}
\hline \multicolumn{2}{|c|}{ Abbreviations } \\
\hline \multicolumn{2}{|c|}{ The following abbreviations are used in this manuscript: } \\
\hline CFPS & cell-free protein synthesis \\
\hline TXTL & transcription and translation \\
\hline DNA & deoxyribonucleic acid \\
\hline RNA & ribonucleic acid \\
\hline NMP & nucleoside monophosphate \\
\hline NTP & nucleoside triphosphate \\
\hline ATP & adenosine triphosphate \\
\hline GTP & guanosine triphosphate \\
\hline NAD & nicotinamide adenine dinucleotide \\
\hline $\mathrm{CoA}$ & coenzyme A \\
\hline mRNA & messenger RNA \\
\hline tRNA & transfer RNA \\
\hline PURE & Protein synthesis Using Recombinant Elements \\
\hline ODE & ordinary differential equation \\
\hline CFME & cell-free metabolic engineering \\
\hline FBA & flux balance analysis \\
\hline MFA & metabolic flux analysis \\
\hline ME & metabolic engineering \\
\hline PCR & polymerase chain reaction \\
\hline
\end{tabular}




\section{References}

1. Albayrak, C.; Jones, K.; Swartz, J.R. Broadening horizons and teaching basic biology through cell-free synthesis of green fluorescent protein in a high school laboratory course. J. Sci. Educ. Technol. 2013, 22, 963-973. [CrossRef]

2. Collias, D.; Marshall, R.; Collins, S.P.; Beisel, C.L.; Noireaux, V. An educational module to explore CRISPR technologies with a cell-free transcription-translation system. Synth. Biol. 2019, 4, ysz005. [CrossRef]

3. Gregorio, N.E.; Levine, M.Z.; Oza, J.P. A user's guide to cell-free protein synthesis. Methods Protoc. 2019, 2, 24. [CrossRef] [PubMed]

4. Borsook, H. Protein turnover and incorporation of labeled amino acids into tissue proteins in vivo and in vitro. Physiol. Rev. 1950, 30, 206-219. [CrossRef]

5. Winnick, T. Incorporation of labeled amino acids into the protein of embryonic and tumor tissue homogenates. Fed. Proc. 1950, 9, 247.

6. Gale, E.F.; Folkes, J.P. Effect of nucleic acids on protein synthesis and amino-acid incorporation in disrupted staphylococcal cells. Nature 1954, 173, 1223-1227. [CrossRef]

7. Hoagland, M.B.; Keller, E.B.; Zamecnik, P.C. Enzymatic carboxyl activation of amino acids. J. Biol. Chem. 1956, 218, 345-358.

8. Matthaei, J.H.; Nirenberg, M.W. Characteristics and stabilization of DNAase-sensitive protein synthesis in E. coli extracts. Proc. Natl. Acad. Sci. USA 1961, 47, 1580. [CrossRef]

9. Nirenberg, M.W.; Matthaei, J.H. The dependence of cell-free protein synthesis in E. coli upon naturally occurring or synthetic polyribonucleotides. Proc. Natl. Acad. Sci. USA 1961, 47, 1588-1602. [CrossRef]

10. Lederman, M.; Zubay, G. DNA-directed peptide synthesis I. A comparison of T2 and Escherichia coli DNA-directed peptide synthesis in two cell-free systems. Biochim. Biophys. Acta (BBA) Nucleic Acids Protein Synth. 1967, 149, 253-258. [CrossRef]

11. Spirin, A.; Baranov, V.; Ryabova, L.; Ovodov, S.; Alakhov, Y. A continuous cell-free translation system capable of producing polypeptides in high yield. Science 1988, 242, 1162-1164. [CrossRef] [PubMed]

12. Kim, D.M.; Swartz, J.R. Regeneration of adenosine triphosphate from glycolytic intermediates for cell-free protein synthesis. Biotechnol. Bioeng. 2001, 74, 309-316. [CrossRef] [PubMed]

13. Jewett, M.C.; Swartz, J.R. Mimicking the Escherichia coli cytoplasmic environment activates long-lived and efficient cell-free protein synthesis. Biotechnol. Bioeng. 2004, 86, 19-26. [CrossRef] [PubMed]

14. Jewett, M.C.; Swartz, J.R. Substrate replenishment extends protein synthesis with an in vitro translation system designed to mimic the cytoplasm. Biotechnol. Bioeng. 2004, 87, 465-471. [CrossRef]

15. Jewett, M.C.; Calhoun, K.A.; Voloshin, A.; Wuu, J.J.; Swartz, J.R. An integrated cell-free metabolic platform for protein production and synthetic biology. Mol. Syst. Biol. 2008, 4, 220. [CrossRef]

16. Calhoun, K.A.; Swartz, J.R. Energizing cell-free protein synthesis with glucose metabolism. Biotechnol. Bioeng. 2005, 90, 606-613. [CrossRef]

17. Garamella, J.; Marshall, R.; Rustad, M.; Noireaux, V. The All E. coli TX-TL Toolbox 2.0: A Platform for Cell-Free Synthetic Biology. ACS Synth. Biol. 2016, 5, 344-355. [CrossRef]

18. Shin, J.; Noireaux, V. Efficient cell-free expression with the endogenous E. coli RNA polymerase and sigma factor 70. J. Biol. Eng. 2010, 4, 8. [CrossRef]

19. Shin, J.; Noireaux, V. An E. coli cell-free expression toolbox: Application to synthetic gene circuits and artificial cells. ACS Synth. Biol. 2012, 1, 29-41. [CrossRef]

20. Rosenblum, G.; Cooperman, B.S. Engine out of the chassis: Cell-free protein synthesis and its uses. FEBS Lett. 2014, 588, 261-268. [CrossRef]

21. Shimizu, Y.; Inoue, A.; Tomari, Y.; Suzuki, T.; Yokogawa, T.; Nishikawa, K.; Ueda, T. Cell-free translation reconstituted with purified components. Nat. Biotechnol. 2001, 19, 751. [CrossRef]

22. Zhou, Y.; Asahara, H.; Gaucher, E.A.; Chong, S. Reconstitution of translation from Thermus thermophilus reveals a minimal set of components sufficient for protein synthesis at high temperatures and functional conservation of modern and ancient translation components. Nucleic Acids Res. 2012, 40, 7932-7945. [CrossRef] [PubMed]

23. Jackson, K.; Jin, S.; Fan, Z.H. Optimization of a miniaturized fluid array device for cell-free protein synthesis. Biotechnol. Bioeng. 2015, 112, 2459-2467. [CrossRef] [PubMed] 
24. Niwa, T.; Sasaki, Y.; Uemura, E.; Nakamura, S.; Akiyama, M.; Ando, M.; Sawada, S.; Mukai, S.A.; Ueda, T.; Taguchi, H.; et al. Comprehensive study of liposome-assisted synthesis of membrane proteins using a reconstituted cell-free translation system. Sci. Rep. 2015, 5, 18025. [CrossRef] [PubMed]

25. Murakami, S.; Matsumoto, R.; Kanamori, T. Constructive approach for synthesis of a functional IgG using a reconstituted cell-free protein synthesis system. Sci. Rep. 2019, 9, 1-13. [CrossRef]

26. Gessesse, B.; Nagaike, T.; Nagata, K.; Shimizu, Y.; Ueda, T. G-protein coupled receptor protein synthesis on a lipid bilayer using a reconstituted cell-free protein synthesis system. Life 2018, 8, 54. [CrossRef]

27. Li, J.; Gu, L.; Aach, J.; Church, G.M. Improved cell-free RNA and protein synthesis system. PLoS ONE 2014, 9, e106232. [CrossRef]

28. Swartz, J.R. Expanding biological applications using cell-free metabolic engineering: An overview. Metab. Eng. 2018, 50, 156-172. [CrossRef]

29. Hillebrecht, J.R.; Chong, S. A comparative study of protein synthesis in in vitro systems: From the prokaryotic reconstituted to the eukaryotic extract-based. BMC Biotechnol. 2008, 8, 58. [CrossRef]

30. Shrestha, P.; Holland, T.M.; Bundy, B.C. Streamlined extract preparation for Escherichia coli-based cell-free protein synthesis by sonication or bead vortex mixing. Biotechniques 2012, 53, 163-174. [CrossRef] [PubMed]

31. Zubay, G. In vitro synthesis of protein in microbial systems. Annu. Rev. Genet. 1973, 7, 267-287. [CrossRef] [PubMed]

32. Pratt, J. Coupled transcription-translation in prokaryotic cell-free systems. In Transcription and Translation: A Practical Approach; IRL Press: New York, NY, USA, 1984; pp. 179-209.

33. Kigawa, T.; Yabuki, T.; Matsuda, N.; Matsuda, T.; Nakajima, R.; Tanaka, A.; Yokoyama, S. Preparation of Escherichia coli cell extract for highly productive cell-free protein expression. J. Struct. Funct. Genom. 2004, 5, 63-68.:JSFG.0000029204.57846.7d. [CrossRef] [PubMed]

34. Liu, D.V.; Zawada, J.F.; Swartz, J.R. Streamlining Escherichia coli S30 extract preparation for economical cell-free protein synthesis. Biotechnol. Prog. 2005, 21, 460-465. [CrossRef]

35. Kim, T.W.; Keum, J.W.; Oh, I.S.; Choi, C.Y.; Park, C.G.; Kim, D.M. Simple procedures for the construction of a robust and cost-effective cell-free protein synthesis system. J. Biotechnol. 2006, 126, 554-561. [CrossRef] [PubMed]

36. Didovyk, A.; Tonooka, T.; Tsimring, L.; Hasty, J. Rapid and scalable preparation of bacterial lysates for cell-free gene expression. ACS Synth. Biol. 2017, 6, 2198-2208. [CrossRef] [PubMed]

37. Calhoun, K.A.; Swartz, J.R. Total amino acid stabilization during cell-free protein synthesis reactions. J. Biotechnol. 2006, 123, 193-203. [CrossRef] [PubMed]

38. Michel-Reydellet, N.; Calhoun, K.; Swartz, J. Amino acid stabilization for cell-free protein synthesis by modification of the Escherichia coli genome. Metab. Eng. 2004, 6, 197-203. [CrossRef] [PubMed]

39. Dudley, Q.M.; Anderson, K.C.; Jewett, M.C. Cell-free mixing of Escherichia coli crude extracts to prototype and rationally engineer high-titer mevalonate synthesis. ACS Synth. Biol. 2016, 5, 1578-1588. [CrossRef]

40. Silverman, A.D.; Kelley-Loughnane, N.; Lucks, J.B.; Jewett, M.C. Deconstructing cell-free extract preparation for in vitro activation of transcriptional genetic circuitry. ACS Synth. Biol. 2018, 8, 403-414. [CrossRef]

41. Pardee, K.; Slomovic, S.; Nguyen, P.Q.; Lee, J.W.; Donghia, N.; Burrill, D.; Ferrante, T.; McSorley, F.R.; Furuta, Y.; Vernet, A.; et al. Portable, On-Demand Biomolecular Manufacturing. Cell 2016, 167, 248-259. [CrossRef]

42. Carlson, E.D.; Gan, R.; Hodgman, C.E.; Jewett, M.C. Cell-free protein synthesis: Applications come of age. Biotechnol. Adv. 2012, 30, 1185-1194. [CrossRef] [PubMed]

43. Lu, Y.; Welsh, J.P.; Swartz, J.R. Production and stabilization of the trimeric influenza hemagglutinin stem domain for potentially broadly protective influenza vaccines. Proc. Natl. Acad. Sci. USA 2014, 111, 125-130. [CrossRef] [PubMed]

44. Goerke, A.R.; Swartz, J.R. Development of cell-free protein synthesis platforms for disulfide bonded proteins. Biotechnol. Bioeng. 2008, 99, 351-367. [CrossRef] [PubMed]

45. Ng, P.P.; Jia, M.; Patel, K.G.; Brody, J.D.; Swartz, J.R.; Levy, S.; Levy, R. A vaccine directed to B cells and produced by cell-free protein synthesis generates potent antilymphoma immunity. Proc. Natl. Acad. Sci. USA 2012, 109, 14526-14531. [CrossRef]

46. Takai, K.; Sawasaki, T.; Endo, Y. Practical cell-free protein synthesis system using purified wheat embryos. Nat. Protoc. 2001, 5, 227. [CrossRef] 
47. Guarino, C.; DeLisa, M.P. A prokaryote-based cell-free translation system that efficiently synthesizes glycoproteins. Glycobiology 2012, 22, 596-601. [CrossRef]

48. Jaroentomeechai, T.; Stark, J.C.; Natarajan, A.; Glasscock, C.J.; Yates, L.E.; Hsu, K.J.; Mrksich, M.; Jewett, M.C.; DeLisa, M.P. Single-pot glycoprotein biosynthesis using a cell-free transcription-translation system enriched with glycosylation machinery. Nat. Commun. 2018, 9, 2686. [CrossRef]

49. Perez, J.G.; Stark, J.C.; Jewett, M.C. Cell-free synthetic biology: Engineering beyond the cell. Cold Spring Harb. Perspect. Biol. 2016, 8, a023853. [CrossRef]

50. Matthies, D.; Haberstock, S.; Joos, F.; Dötsch, V.; Vonck, J.; Bernhard, F.; Meier, T. Cell-free expression and assembly of ATP synthase. J. Mol. Biol. 2011, 413, 593-603. [CrossRef]

51. Wang, X.; Corin, K.; Baaske, P.; Wienken, C.J.; Jerabek-Willemsen, M.; Duhr, S.; Braun, D.; Zhang, S. Peptide surfactants for cell-free production of functional G protein-coupled receptors. Proc. Natl. Acad. Sci. USA 2011, 108, 9049-9054. [CrossRef]

52. Shinoda, T.; Shinya, N.; Ito, K.; Ishizuka-Katsura, Y.; Ohsawa, N.; Terada, T.; Hirata, K.; Kawano, Y.; Yamamoto, M.; Tomita, T.; et al. Cell-free methods to produce structurally intact mammalian membrane proteins. Sci. Rep. 2016, 6, 30442. [CrossRef] [PubMed]

53. Stark, J.C.; Jaroentomeechai, T.; Moeller, T.D.; Dubner, R.S.; Hsu, K.J.; Stevenson, T.C.; DeLisa, M.P.; Jewett, M.C. On-demand, cell-free biomanufacturing of conjugate vaccines at the point-of-care. bioRxiv 2019, 681841. [CrossRef]

54. Jewett, M.C.; Fritz, B.R.; Timmerman, L.E.; Church, G.M. In vitro integration of ribosomal RNA synthesis, ribosome assembly, and translation. Mol. Syst. Biol. 2013, 9, 678. [CrossRef] [PubMed]

55. Fritz, B.R.; Jewett, M.C. The impact of transcriptional tuning on in vitro integrated rRNA transcription and ribosome construction. Nucleic Acids Res. 2014, 42, 6774-6785. [CrossRef] [PubMed]

56. Du, D.; van Veen, H.W.; Luisi, B.F. Assembly and operation of bacterial tripartite multidrug efflux pumps. Trends Microbiol. 2015, 23, 311-319. [CrossRef]

57. Albayrak, C.; Swartz, J.R. Direct polymerization of proteins. ACS Synth. Biol. 2013, 3, 353-362. [CrossRef]

58. Albayrak, C.; Swartz, J.R. Cell-free co-production of an orthogonal transfer RNA activates efficient site-specific non-natural amino acid incorporation. Nucleic Acids Res. 2013, 41, 5949-5963. [CrossRef] [PubMed]

59. Martin, R.W.; Des Soye, B.J.; Kwon, Y.C.; Kay, J.; Davis, R.G.; Thomas, P.M.; Majewska, N.I.; Chen, C.X.; Marcum, R.D.; Weiss, M.G.; et al. Cell-free protein synthesis from genomically recoded bacteria enables multisite incorporation of noncanonical amino acids. Nat. Commun. 2018, 9, 1203. [CrossRef]

60. Qiu, J.; Swartz, J.R.; Georgiou, G. Expression of active human tissue-type plasminogen activator in Escherichia coli. Appl. Environ. Microbiol. 1998, 64, 4891-4896. [CrossRef]

61. Yin, G.; Swartz, J.R. Enhancing multiple disulfide bonded protein folding in a cell-free system. Biotechnol. Bioeng. 2004, 86, 188-195. [CrossRef]

62. Min, S.E.; Lee, K.H.; Park, S.W.; Yoo, T.H.; Oh, C.H.; Park, J.H.; Yang, S.Y.; Kim, Y.S.; Kim, D.M. Cell-free production and streamlined assay of cytosol-penetrating antibodies. Biotechnol. Bioeng. 2016, 113, 2107-2112. [CrossRef] [PubMed]

63. Salehi, A.S.M.; Smith, M.T.; Bennett, A.M.; Williams, J.B.; Pitt, W.G.; Bundy, B.C. Cell-free protein synthesis of a cytotoxic cancer therapeutic: Onconase production and a just-add-water cell-free system. Biotechnol. J. 2015, 11, 274-281. [CrossRef] [PubMed]

64. Hartman, R.L.; McMullen, J.P.; Jensen, K.F. Deciding Whether To Go with the Flow: Evaluating the Merits of Flow Reactors for Synthesis. Angew. Chem. Int. Ed. 2011, 50, 7502-7519. [CrossRef] [PubMed]

65. McQuade, D.T.; Seeberger, P.H. Applying Flow Chemistry: Methods, Materials, and Multistep Synthesis. J. Org. Chem. 2013, 78, 6384-6389. [CrossRef]

66. Georgi, V.; Georgi, L.; Blechert, M.; Bergmeister, M.; Zwanzig, M.; Wüstenhagen, D.A.; Bier, F.F.; Jung, E.; Kubick, S. On-chip automation of cell-free protein synthesis: New opportunities due to a novel reaction mode. Lab Chip 2016, 16, 269-281. [CrossRef]

67. Nge, P.N.; Rogers, C.I.; Woolley, A.T. Advances in Microfluidic Materials, Functions, Integration, and Applications. Chem. Rev. 2013, 113, 2550-2583. [CrossRef]

68. Murphy, T.W.; Sheng, J.; Naler, L.B.; Feng, X.; Lu, C. On-chip manufacturing of synthetic proteins for point-of-care therapeutics. Microsyst. Nanoeng. 2019, 5, 1-12. [CrossRef] 
69. Timm, A.C.; Shankles, P.G.; Foster, C.M.; Doktycz, M.J.; Retterer, S.T. Toward microfluidic reactors for cell-free protein synthesis at the point-of-care. Small 2016, 12, 810-817. [CrossRef]

70. Silverman, A.D.; Karim, A.S.; Jewett, M.C. Cell-free gene expression: An expanded repertoire of applications. Nat. Rev. Genet. 2019, 21, 151-170. [CrossRef]

71. Voloshin, A.M.; Swartz, J.R. Efficient and scalable method for scaling up cell-free protein synthesis in batch mode. Biotechnol. Bioeng. 2005, 91, 516-521. [CrossRef]

72. Swartz, J. Developing cell-free biology for industrial applications. J. Ind. Microbiol. Biotechnol. 2006, 33, 476-485. [CrossRef] [PubMed]

73. Zawada, J.F.; Yin, G.; Steiner, A.R.; Yang, J.; Naresh, A.; Roy, S.M.; Gold, D.S.; Heinsohn, H.G.; Murray, C.J. Microscale to manufacturing scale-up of cell-free cytokine production-a new approach for shortening protein production development timelines. Biotechnol. Bioeng. 2011, 108, 1570-1578. [CrossRef]

74. Ogonah, O.W.; Polizzi, K.M.; Bracewell, D.G. Cell-free protein synthesis: A viable option for stratified medicines manufacturing? Curr. Opin. Chem. Eng. 2017, 18, 77-83. [CrossRef]

75. Yin, G.; Garces, E.D.; Yang, J.; Zhang, J.; Tran, C.; Steiner, A.R.; Roos, C.; Bajad, S.; Hudak, S.; Penta, K.; et al. Aglycosylated antibodies and antibody fragments produced in a scalable in vitro transcription-translation system. MAbs 2012, 4, 217-225. [CrossRef] [PubMed]

76. Ma, D.; Shen, L.; Wu, K.; Diehnelt, C.W.; Green, A.A. Low-cost detection of norovirus using paper-based cell-free systems and synbody-based viral enrichment. Synth. Biol. 2018, 3, ysy018. [CrossRef]

77. Pardee, K.; Green, A.A.; Ferrante, T.; Cameron, D.E.; DaleyKeyser, A.; Yin, P.; Collins, J.J. Paper-based synthetic gene networks. Cell 2014, 159, 940-954. [CrossRef]

78. Pardee, K.; Green, A.A.; Takahashi, M.K.; Braff, D.; Lambert, G.; Lee, J.W.; Ferrante, T.; Ma, D.; Donghia, N.; Fan, M.; et al. Rapid, low-cost detection of Zika virus using programmable biomolecular components. Cell 2016, 165, 1255-1266. [CrossRef]

79. Gräwe, A.; Dreyer, A.; Vornholt, T.; Barteczko, U.; Buchholz, L.; Drews, G.; Ho, U.L.; Jackowski, M.E.; Kracht, M.; Lüders, J.; et al. A paper-based, cell-free biosensor system for the detection of heavy metals and date rape drugs. PLoS ONE 2019, 14, e0210940. [CrossRef]

80. Morowitz, H.J. The completeness of molecular biology. ISR J. Med. Sci. 1984, 20, 750-753.

81. Garenne, D.; Noireaux, V. Cell-free transcription-translation: Engineering biology from the nanometer to the millimeter scale. Curr. Opin. Biotechnol. 2019, 58, 19-27. [CrossRef]

82. Ishikawa, K.; Sato, K.; Shima, Y.; Urabe, I.; Yomo, T. Expression of a cascading genetic network within liposomes. FEBS Lett. 2004, 576, 387-390. [CrossRef] [PubMed]

83. Noireaux, V.; Libchaber, A. A vesicle bioreactor as a step toward an artificial cell assembly. Proc. Natl. Acad. Sci. USA 2004, 101, 17669-17674. [CrossRef] [PubMed]

84. Karzbrun, E.; Tayar, A.M.; Noireaux, V.; Bar-Ziv, R.H. Programmable on-chip DNA compartments as artificial cells. Science 2014, 345, 829-832. [CrossRef] [PubMed]

85. Pereira de Souza, T.; Stano, P.; Luisi, P.L. The minimal size of liposome-based model cells brings about a remarkably enhanced entrapment and protein synthesis. ChemBioChem 2009, 10, 1056-1063. [CrossRef] [PubMed]

86. Zhou, X.; Wu, H.; Cui, M.; Lai, S.N.; Zheng, B. Long-lived protein expression in hydrogel particles: Towards artificial cells. Chem. Sci. 2018, 9, 4275-4279. [CrossRef] [PubMed]

87. Tayar, A.M.; Karzbrun, E.; Noireaux, V.; Bar-Ziv, R.H. Synchrony and pattern formation of coupled genetic oscillators on a chip of artificial cells. Proc. Natl. Acad. Sci. USA 2017, 114, 11609-11614. [CrossRef]

88. Niederholtmeyer, H.; Sun, Z.Z.; Hori, Y.; Yeung, E.; Verpoorte, A.; Murray, R.M.; Maerkl, S.J. Rapid cell-free forward engineering of novel genetic ring oscillators. Elife 2015, 4, e09771. [CrossRef]

89. Karig, D.K.; Iyer, S.; Simpson, M.L.; Doktycz, M.J. Expression optimization and synthetic gene networks in cell-free systems. Nucleic Acids Res. 2011, 40, 3763-3774. [CrossRef]

90. Martini, L.; Mansy, S.S. Measuring Riboswitch Activity In Vitro and in Artificial Cells with Purified Transcription-Translation Machinery. In Artificial Riboswitches; Humana Press: Totowa, NJ, USA, 2014; pp. 153-164.

91. Adamala, K.P.; Martin-Alarcon, D.A.; Guthrie-Honea, K.R.; Boyden, E.S. Engineering genetic circuit interactions within and between synthetic minimal cells. Nat. Chem. 2017, 9, 431. [CrossRef] 
92. Hamada, S.; Yancey, K.G.; Pardo, Y.; Gan, M.; Vanatta, M.; An, D.; Hu, Y.; Derrien, T.L.; Ruiz, R.; Liu, P.; et al. Dynamic DNA material with emergent locomotion behavior powered by artificial metabolism. Sci. Robot. 2019, 4, eaaw3512. [CrossRef]

93. Moore, S.J.; MacDonald, J.T.; Wienecke, S.; Ishwarbhai, A.; Tsipa, A.; Aw, R.; Kylilis, N.; Bell, D.J.; McClymont, D.W.; Jensen, K.; et al. Rapid acquisition and model-based analysis of cell-free transcription-translation reactions from nonmodel bacteria. Proc. Natl. Acad. Sci. USA 2018, 115, E4340-E4349. [CrossRef] [PubMed]

94. Niederholtmeyer, H.; Xu, L.; Maerkl, S.J. Real-time mRNA measurement during an in vitro transcription and translation reaction using binary probes. ACS Synth. Biol. 2012, 2, 411-417. [CrossRef] [PubMed]

95. Damiati, S.; Mhanna, R.; Kodzius, R.; Ehmoser, E.K. Cell-free approaches in synthetic biology utilizing microfluidics. Genes 2018, 9, 144. [CrossRef] [PubMed]

96. Sakamoto, R.; Noireaux, V.; Maeda, Y.T. Anomalous scaling of gene expression in confined cell-free reactions. Sci. Rep. 2018, 8, 7364. [CrossRef]

97. Guo, W.; Sheng, J.; Feng, X. Mini-review: In vitro Metabolic Engineering for Biomanufacturing of High-value Products. Comput. Struct. Biotechnol. J. 2017, 15, 161-167. [CrossRef]

98. Dudley, Q.M.; Karim, A.S.; Jewett, M.C. Cell-free metabolic engineering: Biomanufacturing beyond the cell. Biotechnol. J. 2015, 10, 69-82. [CrossRef]

99. Opgenorth, P.H.; Korman, T.P.; Bowie, J.U. A synthetic biochemistry molecular purge valve module that maintains redox balance. Nat. Commun. 2014, 5, 4113. [CrossRef]

100. Opgenorth, P.H.; Korman, T.P.; Bowie, J.U. A synthetic biochemistry module for production of bio-based chemicals from glucose. Nat. Chem. Biol. 2016, 12, 393-395. [CrossRef]

101. Valliere, M.A.; Korman, T.P.; Woodall, N.B.; Khitrov, G.A.; Taylor, R.E.; Baker, D.; Bowie, J.U. A cell-free platform for the prenylation of natural products and application to cannabinoid production. Nat. Commun. 2019, 10, 565. [CrossRef]

102. Chen, X.; Zhang, C.; Zou, R.; Stephanopoulos, G.; Too, H.P. In Vitro Metabolic Engineering of Amorpha-4,11-diene Biosynthesis at Enhanced Rate and Specific Yield of Production. ACS Synth. Biol. 2017, 6, 1691-1700. [CrossRef]

103. Chen, X.; Zhang, C.; Zou, R.; Zhou, K.; Stephanopoulos, G.; Too, H.P. Statistical experimental design guided optimization of a one-pot biphasic multienzyme total synthesis of amorpha-4,11-diene. PLoS ONE 2013, 8, e79650. [CrossRef] [PubMed]

104. Guterl, J.K.; Garbe, D.; Carsten, J.; Steffler, F.; Sommer, B.; Reiße, S.; Philipp, A.; Haack, M.; Rühmann, B.; Koltermann, A.; et al. Cell-free metabolic engineering: Production of chemicals by minimized reaction cascades. ChemSusChem 2012, 5, 2165-2172. [CrossRef] [PubMed]

105. Krutsakorn, B.; Honda, K.; Ye, X.; Imagawa, T.; Bei, X.; Okano, K.; Ohtake, H. In vitro production of n-butanol from glucose. Metab. Eng. 2013, 20, 84-91. [CrossRef] [PubMed]

106. Bechtold, M.; Brenna, E.; Femmer, C.; Gatti, F.G.; Panke, S.; Parmeggiani, F.; Sacchetti, A. Biotechnological development of a practical synthesis of ethyl (S)-2-ethoxy-3-(p-methoxyphenyl) propanoate (EEHP): Over 100-fold productivity increase from yeast whole cells to recombinant isolated enzymes. Org. Process Res. Dev. 2011, 16, 269-276. [CrossRef]

107. Zhu, Z.; Tam, T.K.; Sun, F.; You, C.; Zhang, Y.H.P. A high-energy-density sugar biobattery based on a synthetic enzymatic pathway. Nat. Commun. 2014, 5, 3026. [CrossRef]

108. Dudley, Q.M.; Nash, C.J.; Jewett, M.C. Cell-free biosynthesis of limonene using enzyme-enriched Escherichia coli lysates. Synth. Biol. 2019, 4, ysz003. [CrossRef]

109. Alonso-Gutierrez, J.; Kim, E.M.; Batth, T.S.; Cho, N.; Hu, Q.; Chan, L.J.G.; Petzold, C.J.; Hillson, N.J.; Adams, P.D.; Keasling, J.D.; et al. Principal component analysis of proteomics (PCAP) as a tool to direct metabolic engineering. Metab. Eng. 2015, 28, 123-133. [CrossRef]

110. Yi, T.; Lim, H.J.; Lee, S.J.; Lee, K.H.; Kim, D.M. Synthesis of (R,R)-2,3-butanediol from starch in a hybrid cell-free reaction system. J. Ind. Eng. Chem. 2018, 67, 231-235. [CrossRef]

111. Calhoun, K.A.; Swartz, J.R. An Economical Method for Cell-Free Protein Synthesis using Glucose and Nucleoside Monophosphates. Biotechnol. Prog. 2005, 21, 1146-1153. [CrossRef]

112. Welsh, J.P.; Lu, Y.; He, X.S.; Greenberg, H.B.; Swartz, J.R. Cell-free production of trimeric influenza hemagglutinin head domain proteins as vaccine antigens. Biotechnol. Bioeng. 2012, 109, 2962-2969. [CrossRef] 
113. Boyer, M.E.; Stapleton, J.A.; Kuchenreuther, J.M.; Wang, C.W.; Swartz, J.R. Cell-free synthesis and maturation of [FeFe] hydrogenases. Biotechnol. Bioeng. 2008, 99, 59-67. [CrossRef] [PubMed]

114. Bogorad, I.W.; Lin, T.S.; Liao, J.C. Synthetic non-oxidative glycolysis enables complete carbon conservation. Nature 2013, 502, 693. [CrossRef]

115. Bailey, J. Toward a science of metabolic engineering. Science 1991, 252, 1668-1675. [CrossRef] [PubMed]

116. Karzbrun, E.; Shin, J.; Bar-Ziv, R.H.; Noireaux, V. Coarse-Grained Dynamics of Protein Synthesis in a Cell-Free System. Phys. Rev. Lett. 2011, 106. [CrossRef] [PubMed]

117. Stögbauer, T.; Windhager, L.; Zimmer, R.; Rädler, J.O. Experiment and mathematical modeling of gene expression dynamics in a cell-free system. Integr. Biol. 2012, 4, 494-501. [CrossRef] [PubMed]

118. Nieß, A.; Failmezger, J.; Kuschel, M.; Siemann-Herzberg, M.; Takors, R. Experimentally Validated Model Enables Debottlenecking of in Vitro Protein Synthesis and Identifies a Control Shift under in Vivo Conditions. ACS Synth. Biol. 2017, 6, 1913-1921. [CrossRef]

119. Gyorgy, A.; Murray, R.M. Quantifying resource competition and its effects in the TX-TL system. In Proceedings of the 2016 IEEE 55th Conference on Decision and Control (CDC), Las Vegas, NV, USA, 12-14 December 2016; pp. 3363-3368. [CrossRef]

120. Lucks, J.B.; Qi, L.; Mutalik, V.K.; Wang, D.; Arkin, A.P. Versatile RNA-sensing transcriptional regulators for engineering genetic networks. Proc. Natl. Acad. Sci. USA 2011, 108, 8617-8622. [CrossRef]

121. Brantl, S.; Wagner, E.G.H. Antisense RNA-mediated transcriptional attenuation: An in vitro study of plasmid pT181. Mol. Microbiol. 2000, 35, 1469-1482. [CrossRef]

122. Chappell, J.; Takahashi, M.K.; Lucks, J.B. Creating small transcription activating RNAs. Nat. Chem. Biol. 2015, 11, 214-220. [CrossRef]

123. Hu, C.Y.; Varner, J.D.; Lucks, J.B. Generating Effective Models and Parameters for RNA Genetic Circuits. ACS Synth. Biol. 2015, 4, 914-926. [CrossRef]

124. Fredrickson, A.G. Formulation of structured growth models. Biotechnol. Bioeng. 1976, 18, 1481-1486. [CrossRef] [PubMed]

125. Domach, M.M.; Leung, S.K.; Cahn, R.E.; Cocks, G.G.; Shuler, M.L. Computer model for glucose-limited growth of a single cell of Escherichia coli B/r-A. Biotechnol. Bioeng. 1984, 26, 203-216. [CrossRef] [PubMed]

126. Steinmeyer, D.; Shuler, M. Structured model for Saccharomyces cerevisiae. Chem. Eng. Sci. 1989, 44, 2017-2030. [CrossRef]

127. Wu, P.; Ray, N.G.; Shuler, M.L. A single-cell model for CHO cells. Ann. N. Y. Acad. Sci. 1992, 665, $152-187$. [CrossRef] [PubMed]

128. Castellanos, M.; Wilson, D.B.; Shuler, M.L. A modular minimal cell model: Purine and pyrimidine transport and metabolism. Proc. Natl. Acad. Sci. USA 2004, 101, 6681-6686. [CrossRef]

129. Atlas, J.C.; Nikolaev, E.V.; Browning, S.T.; Shuler, M.L. Incorporating genome-wide DNA sequence information into a dynamic whole-cell model of Escherichia coli: Application to DNA replication. IET Syst. Biol. 2008, 2, 369-382. [CrossRef]

130. Tomita, M.; Hashimoto, K.; Takahashi, K.; Shimizu, T.S.; Matsuzaki, Y.; Miyoshi, F.; Saito, K.; Tanida, S.; Yugi, K.; Venter, J.C.; et al. E-CELL: Software environment for whole-cell simulation. Bioinformatics 1999, 15, 72-84. [CrossRef]

131. Karr, J.R.; Sanghvi, J.C.; Macklin, D.N.; Gutschow, M.V.; Jacobs, J.M.; Bolival, B.; Assad-Garcia, N.; Glass, J.I.; Covert, M.W. A whole-cell computational model predicts phenotype from genotype. Cell 2012, 150, 389-401. [CrossRef]

132. Varma, A.; Palsson, B.O. Stoichiometric flux balance models quantitatively predict growth and metabolic by-product secretion in wild-type Escherichia coli W3110. Appl. Environ. Microbiol. 1994, 60, 3724-3731. [CrossRef]

133. Lewis, N.E.; Nagarajan, H.; Palsson, B.Ø. Constraining the metabolic genotype-phenotype relationship using a phylogeny of in silico methods. Nat. Rev. Microbiol. 2012, 10, 291-305. [CrossRef]

134. Wiechert, W. 13C Metabolic Flux Analysis. Metabol. Eng. 2001, 3, 195-206. [CrossRef]

135. Schuster, S.; Fell, D.A.; Dandekar, T. A general definition of metabolic pathways useful for systematic organization and analysis of complex metabolic networks. Nat. Biotechnol. 2000, 18, 326-332. [CrossRef] [PubMed] 
136. Schilling, C.H.; Letscher, D.; Palsson, B.O. Theory for the systemic definition of metabolic pathways and their use in interpreting metabolic function from a pathway-oriented perspective. J. Theor. Biol. 2000, 203, 229-248. [CrossRef]

137. Henry, C.S.; Broadbelt, L.J.; Hatzimanikatis, V. Thermodynamics-Based Metabolic Flux Analysis. Biophys. J. 2006, 92, 1792-1805. [CrossRef] [PubMed]

138. Hamilton, J.J.; Dwivedi, V.; Reed, J.L. Quantitative Assessment of Thermodynamic Constraints on the Solution Space of Genome-Scale Metabolic Models. Biophys. J. 2013, 105, 512-522. [CrossRef] [PubMed]

139. Covert, M.W.; Knight, E.M.; Reed, J.L.; Herrgard, M.J.; Palsson, B.O. Integrating high-throughput and computational data elucidates bacterial networks. Nature 2004, 429, 92-96. [CrossRef]

140. Sánchez, C.; Quintero, J.C.; Ochoa, S. Flux balance analysis in the production of clavulanic acid by Streptomyces clavuligerus. Biotechnol. Prog. 2015, 31, 1226-1236. [CrossRef]

141. Edwards, J.S.; Palsson, B.O. Metabolic flux balance analysis and the in silico analysis of Escherichia coli K-12 gene deletions. BMC Bioinform. 2000, 1, 1. [CrossRef]

142. O’Brien, E.J.; Lerman, J.A.; Chang, R.L.; Hyduke, D.R.; Palsson, B.Ø. Genome-scale models of metabolism and gene expression extend and refine growth phenotype prediction. Mol. Syst. Biol. 2013, 9, 693. [CrossRef]

143. Atsumi, S.; Hanai, T.; Liao, J.C. Non-fermentative pathways for synthesis of branched-chain higher alcohols as biofuels. Nature 2008, 451, 86-89. [CrossRef]

144. Nakamura, C.E.; Whited, G.M. Metabolic engineering for the microbial production of 1,3-propanediol. Curr. Opin. Biotechnol. 2003, 14, 454-459. [CrossRef] [PubMed]

145. Song, H.; Lee, S.Y. Production of succinic acid by bacterial fermentation. Enzym. Microb. Technol. 2006, 39, 352-361. [CrossRef]

146. Yim, H.; Haselbeck, R.; Niu, W.; Pujol-Baxley, C.; Burgard, A.; Boldt, J.; Khandurina, J.; Trawick, J.D.; Osterhout, R.E.; Stephen, R.; et al. Metabolic engineering of Escherichia coli for direct production of 1,4-butanediol. Nat. Chem. Biol. 2011, 7, 445-452. [CrossRef] [PubMed]

147. Ro, D.K.; Paradise, E.M.; Ouellet, M.; Fisher, K.J.; Newman, K.L.; Ndungu, J.M.; Ho, K.A.; Eachus, R.A.; Ham, T.S.; Kirby, J.; et al. Production of the antimalarial drug precursor artemisinic acid in engineered yeast. Nature 2006, 440, 940-943. [CrossRef]

148. Fossati, E.; Ekins, A.; Narcross, L.; Zhu, Y.; Falgueyret, J.P.; Beaudoin, G.A.W.; Facchini, P.J.; Martin, V.J.J. Reconstitution of a 10-gene pathway for synthesis of the plant alkaloid dihydrosanguinarine in Saccharomyces cerevisiae. Nat. Commun. 2014, 5, 1-11. [CrossRef]

149. Allen, T.E.; Palsson, B.Ø. Sequence-based analysis of metabolic demands for protein synthesis in prokaryotes. J. Theor. Biol. 2003, 220,1-18. [CrossRef]

150. Thiele, I.; Jamshidi, N.; Fleming, R.M.T.; Palsson, B.O. Genome-Scale Reconstruction of Escherichia coli's Transcriptional and Translational Machinery: A Knowledge Base, Its Mathematical Formulation, and Its Functional Characterization. PLoS Comput. Biol. 2009, 5, 1-13. [CrossRef]

151. Zhang, Y.; Thiele, I.; Weekes, D.; Li, Z.; Jaroszewski, L.; Ginalski, K.; Deacon, A.M.; Wooley, J.; Lesley, S.A.; Wilson, I.A.; et al. Three-Dimensional Structural View of the Central Metabolic Network of Thermotoga maritima. Science 2009, 325, 1544-1549. [CrossRef]

152. Chang, R.L.; Andrews, K.; Kim, D.; Li, Z.; Godzik, A.; Palsson, B.O. Structural Systems Biology Evaluation of Metabolic Thermotolerance in Escherichia coli. Science 2013, 340, 1220-1223. [CrossRef]

153. Dai, D.; Horvath, N.; Varner, J. Dynamic Sequence Specific Constraint-Based Modeling of Cell-Free Protein Synthesis. Processes 2018, 6, 132. [CrossRef]

154. Vilkhovoy, M.; Horvath, N.; Shih, C.H.; Wayman, J.A.; Calhoun, K.; Swartz, J.; Varner, J.D. Sequence Specific Modeling of E. coli Cell-Free Protein Synthesis. ACS Synth. Biol. 2018, 7, 1844-1857. [CrossRef] [PubMed]

155. Horvath, N.; Vilkhovoy, M.; Wayman, J.A.; Calhoun, K.; Swartz, J.; Varner, J.D. Toward a Genome Scale Sequence Specific Dynamic Model of Cell-Free Protein Synthesis in Escherichia coli. Metab. Eng. Commun. 2020, 10, e00113. [CrossRef] [PubMed]

156. Wayman, J.A.; Sagar, A.; Varner, J.D. Dynamic Modeling of Cell-Free Biochemical Networks Using Effective Kinetic Models. Processes 2015, 3, 138. [CrossRef] 
157. Vilkhovoy, M.; Dai, D.; Vadhin, S.; Adhikari, A.; Varner, J.D. Absolute Quantification of Cell-Free Protein Synthesis Metabolism by Reversed-Phase Liquid Chromatography-Mass Spectrometry. J. Vis. Exp. 2019. [CrossRef]

158. Smith, M.T.; Bennett, A.M.; Hunt, J.M.; Bundy, B.C. Creating a completely "cell-free" system for protein synthesis. Biotechnol. Prog. 2015, 31, 1716-1719. [CrossRef] 